\title{
MANAGEMEN KONFLIK (UPAYA PENYELESAIAN KONFLIK DALAM ORGANISASI SEKOLAH DI SMP MUHAMMADIYAH AL-MANAR BOARDING SCHOOL)
}

\author{
Meti Andani1 ${ }^{1}$ Farid Setiawan², Rahma Haifani Azizah², \\ Dian Sidik Kurniawan ${ }^{4}$, Pathur Rahman $1^{5}$ \\ E-mail: meti1911331036@webmail.uad.ac.id / 081229452145 \\ ${ }^{1}$ Universitas Ahmad Dahlan
}

\begin{abstract}
ABSTRAK
Dalam setiap organisai, kehadiran konflik merupakan suatu hal yang wajar. Karena kualitas organisasi dikatakan baik apabila mampu menyelesaikan masalah yang hadir. Demikian pula pemimpin, yang mana memiliki kedudukan tertinggi dan berwenang penuh dalam mengarahkan anggota di dalam organisasi. Selain itu seorang pemimpin juga harus memiliki kemampuan dalam memanagemen konflik, yang mana dapat melihat kondisi dan latar belakang konflik, penyebab konflik, dan cara penyelesaian konflik. Tulisan ini membahas mengenai menagemen konflik. Managemen koflik merupakan upaya penyelesaian dan pengendalian konflik, yang dalam penanganannya membutuhkan keterampilan tertentu. Metode yang digunakan adalah kualitatif, yaitu dengan wawancara langsung terhadap pemimpin organisasi atau kepala sekolah. Dalam memanage konflik, kepala sekola melakukan sosialisasi kepada para guru untuk memberikan pemahaman yang lurus terkait kebijakan yang ditetapkan.
\end{abstract}

Kata Kunci: Organisasi Sekolah, Kepala Sekolah, Managemen Konflik.

\begin{abstract}
In every organization, the presence of conflict is a natural thing. Because the quality of the organization is said to be good if it is able to solve the problems that are present. Likewise, the leader, who has the highest position and has full authority in directing members in the organization. In addition, a leader must also have the ability to manage conflict, which can see the conditions and background of the conflict, the causes of the conflict, and how to resolve the conflict. This paper discusses conflict management. Conflict management is an effort to resolve and control conflict, which in handling requires certain skills. The method used is qualitative, namely by direct interviews with organizational leaders or school principals.
\end{abstract}

Keywords: School Organization, Headmaster, Conflict Management. 


\section{PENDAHULUAN}

Pendidikan merupakan usaha sadar yang dilakukan untuk menyiapkan peserta didik dengan kegiatan pengarahan baik dari bimbingan, maupun pengajaran. Dalam setiap lembaga pendidikan tentu terdapat organisasi untuk mengelola sekolah dengan baik, benar, serta visioner. Tujuan dari organisasi yaitu untuk mencapai visi misi yang telah direncanakan, adapun dalam pelaksanaanya dibutuhkan kerja sama antara para anggota agar langkah yang dilakukan dapat terlaksana sesuai dengan kesepakatan yang telah di musyawarahkan.

Pemimpin merupakan orang pertama yang bertanggung jawab atas apa yang ada dalam naungannya, baik terhadap anggota, kebijakan, program kerja, dan lain sebagainya. Demikian juga dengan pemimpin sekolah atau kepala sekolah, eksistensinya begitu dibutuhkan, terlebih jika memiliki kompetensi yang baik dalam mengelola dan membina sekolah. Adapun kompetensi yang harus dimiliki kepala sekolah, salah satunya adalah kemampuan manajerial. Manajerial merupakan kemampuan yang mengarahkan kepala sekolah agar dapat menyusun rencana, kemudian mengembangkan, mampu mengatasi dengan bijaksana, serta dapat memangku sumber daya manusia dan sekitarnya. Selain dari pada itu, kemampuan manajerial ini dimaksudkan untuk menciptakan kultur sekolah yang efisien dan kondusif.

Setiap organisasi yang terdiri dari banyak orang, sudah pasti banyak pula perbedaan pemikiran. Maka tak jarang perbedaan tersebut dapat memunculkan kesalah pahaman, ketidakcocokan, serta pertentangan-pertentangan hadir dalam setiap organisasi, dan hal ini sangatlah wajar terjadi dalam badan ke-Organisasian. Menjadi tantangan bagi seorang pemimpin dalam mengatasi persoalan yang demikian, karena tugas ini menjadi permasalahan yang krusial sebab dalam penanganannya dibutuhkan kompetensi yang terstruktur guna pemecahan masalah agar dapat diatasi. Dalam hal ini kemampuan yang juga harus dimiliki oleh kepala sekolah adalah kemampuan managemen konflik. Meskipun konflik merupakan suatu hal yang wajar, namun dalam penanganannya dibutuhkan ilmu agar menghasilkan managemen yang baik, terarah, dan terencana sehingga konflik yang ada tidak mengakar menjadi permasalahan yang besar serta mengancurkan tatanan lembaga pendidikan. Dalam hal ini, keberhasilan melakukan strategi manajemen konflik juga dipengaruhi dan ditentukan oleh kepala sekolah sebagai bagian dari output pemimpin sekolah.

\section{METODE}

Dalam penelitian ini penulis menggunakan metode kualitatif, yang mana hasil dari metode ini berupa olahan data yang bersifat deskriptif, misalnya seperti transkripsi wawancara, dokumentasi (gambar, foto, rekaman video), catatan lapangan, dan lain sebagainya (Poerwandari, 1998:29). Titik fokus dalam penelitian ini berpusat pada wawancara. Wawancara merupakan bentuk tanya jawab langsung yang dilakukan antara pewawancara dan orang yang diwawacarai dengan tujuan untuk mendapatkan data yang dibutuhkan oleh pewawancara. Adapun dalam tekniknya peneliti menggunakan wawancara terstruktur, yang mana pewawancara telah menyiapkan pertanyaan-pertanyaan yang telah disusun dengan sistematis kemudian diajukan kepada narasumber untuk memperoleh jawaban yang dibutuhkan.

\section{HASIL DAN PEMBAHASAN}

\section{Hasil Pengertian Managemen Konflik}

Kamus Besar Bahasa Indonesia mengartikan kata konflik dalam adalah percekcokan, perselisihan atau pertentangan (Departemen Pendidikan Nasional, 2008:723). Dari pengertian ini menunjukkan bahwa konflik merupakan sebuah kondisi atau keadaan terjadinya sebuah peristiwa yaitu percekcokan, perselisihan atau pertentangan. Kata percekcokan itu sendiri memiliki kata dasar cekcok yang memiliki arti bertengkar, berbantah atau berselisih (Departemen Pendidikan Nasional, 2008:252). Bertengkar menunjukkan keadaan dimana dua orang atau dua kelompok orang saling berlawanan dengan menunjukkan ia yang benar sedangkan orang lain salah. Kondisi ini menjadikan antar kedua orang atau kedua kelompok saling berebut untuk menang.

Konflik merupakan suatu kondisi tidak menyenangkan yang terjadi dan sering ditemui dalam kehidupan sehari-hari. Entah itu dialami oleh diri sendiri, keluarga, sekolah, masyarakat ataupun dalam lingkup yang luas. Konflik bisa saja ditemui tanpa disengaja, baik disadari ataupun tidak. Ia bisa saja tiba-tiba muncul dan hadir di tengah-tengah kesibukan seseorang misalnya kehidupan rumah tangga, tempat bekerja, bermasyarakat, beragama, berbangsa dan bernegara. Dimanapun seseorang berada, konflik bisa saja terjadi. jika tidak terjadi karena diri sendiri, konflik dapat terjadi disebabkan oleh perilaku orang lain.

Konflik merupakan suatu perjuangan oleh pihak untuk memperoleh suatu pencapaian yang langka, otoritas, kekuasaan dan lain-lain, konflik adalah hubungan antara dua pihak yang memiliki sasaran atau tujuan yang tidak sejalan. Keduanya saling memiliki benturan baik secara pemikiran 
maupun tujuan yang lainnya, karena beberapa perbedaan pendapat, nilai, situasi maupun kondisi dan juga hal lainnya yang bersifat bertentangan. Kemudian konflik dihubungkan dengan peristiwa petualangan, hal-hal baru, pembaharuan, perencanaan, kreasi, rasionalitas yang dialektis, yang mana hakikatnya konflik harus cepat diselesaikan atas pandangan dan metode serta strateginya agar keberlangsungan akan suatu perjalanan cepat teratasi dan berjalan dengan sebagaimana mungkin.

Managemen Konflik merupakan suatu pengendalian konflik/masalah yang sedang terjadi, disini keterampilan memanagemen sangat dibutuhkan. Kemudian managemen konflik yang baik itu selalu mengimplementasikan prinsip serta strategi guna menjadikan sebuah managemen yang tertata dan terdapat sinkronisasi antara kedua belah pihak atau lebih yang bertujuan untuk melerai konflik, sebelum konflik muncul dipermukaan.

\section{Jenis-jenis Konflik}

Kata Mulyasa (2003: 243-244) Mengenai Jenis konfik dalam Kampus atau Sekolah meliputi intrapersonal, interpersonal, intragroup, intergroup, intraorganisasi, dan interorganisasi.

1. Intrapersonal. Konflik ini biasanya berupa konflik yang datang dari diri sendiri. Misal, konflik di organisasi yang mana kita tidak mampu dalam membagi waktu antara berorganisasi dengan tugas kampus.

2. Konflik Interpersonal. Konflik ini disebut juga sebagai konflik yang ada pada setiap individu.

3. Konflik Intragroup, biasanya terjadi antara satu orang dengan yang lainnya dalam suatu kelompok, group ataupun organisasi.

4. Konflik Intergroup, konflik ini biasanya terjadi antar kelompok satu dengan kelompok lainnya.

5. Konflik Intraorganisasi. Konflik ini terjadi dalam suatu organisasi. Misal, konflik vertikal (pemimpin dengan bawahan), horizontal (karyawan dengan karyawan), lini-staf (perbedaan pandangan antar staf), dan juga konflik peran (Terjadi jika satu orang memiliki 2 peran sekaligus dalam jabatan).

6. Konflik Interorganisasi (Konflik antar organisasi).

Latar Belakang dan Struktural Organisasi Sekolah Sekolah adalah suatu sistem pendidikan yang dirancang untuk pembelajaran peserta didik dibawah pengawasan guru dan juga untuk membantu meningkatkan sumber daya manusia yang unggul. Pendidikan yang diterima oleh peserta didik dibangku sekolah, diharapkan mampu melahirkan peingkatkan pola pikir dan kreatifitas peserta didik. Di dalam undang-undang Pendidikan No 20 tahun 2003 tentang sistem pendidikan Nasional (Sisdiknas) pendidikan dasar merupakan pendidikan untuk melandasi pendidikan menengah. Pendidikan dasar terdiri dari sekolah dasar (SD) dan madrasah ibtidaiyah (MI), serta sekolah menengah pertama (SMP) dan madrasah tsanawiyah (MTS).

SMP Muhammadiyah Sewu Galur berdiri pada bulan Agustus tahun 1955, hingga pada tahun 1990 SMP Muhammadiyah Sewu Galur ini berubah menjadi SMP Muhammadiyah 1 Galur. Ditahun 1955 sampai 1990 jumlah murid masih stabil, dan belum ditemukan persoalan yang serius di dalam sekolah karena masih berjalan dengan baik, kemudian ditahun 1996 banyak sekali penurunan jumlah siswa karena banyak sekolah lain yang menambah jumlah kelas seperti di SMP Negeri dan MTS Negeri yang menjadikan ketertarikan anak-anak untuk melanjutkan di sekolah tersebutt, sehingga mengakibatkan penurunan siswa di SMP Muhammadiyah 1 Galur. Pada tahun 2006-2007 terjadi penurunan yang signifikan, hanya ada kelas 9 yang berjumlah 6 anak pada akhir tahun dan dalam menyelenggarakan Ujian Nasional nilai prestasi nilai prestasi siswa menurun, karena tidak ada satu anak pun yang lulus. Kemudian pada akhir tahun 2006-2007 tidak ada siswa di sekolah. Hingga kemudian diadakanlah pertemuan pimpinan daerah untuk menindaklanjuti keberlangsungan sekolah dengan menghasilkan keputusan yang disepakati bahwa, pengembangan SMP Muhammadiyah 1 Galur tetap diteruskan bersama dengan Pondok Pesantren Al-Manar Muhammadiyah, dengan ini akhirnya tim bekerja dan membuat kriteria bahwa anak-anak yang sekolah di SMP Muhammadiyah 1 Galur harus tinggal di asrama, baik rumahnya yang jauh maupun yang dekat dengan pesantren.

Hingga pada tahun 2008-2009 perkembangan SMP ini masih sama, dan ditahun 2009-2010 dalam rangka penguatan dalam pengembangan, maka disepakati diadakan Boarding School, ditahun 20102011 SMP Muhammadiyah 1 Galur dan Pondok Pesantren Al-Manar telah disahkan, bahwa Pondok Pesantren Al-Manar bagian dari SMP Muhammadiyah 1 Galur, yang pada akhirnya nama sekolah berubah menjadi SMP Muhammadiyah AlManar Boarding School hingga saat ini. Dalam pengembangan bersama Pondok Pesantren Al-Manar Muhammadiyah, maka secara struktural sekolah ini dibawah pondok pesantren dan keduanya berada dibawah tanggung jawab Majelis Pendidikan Dasar dan Menegah (Dikdasmen) serta Pimpinan Daerah Muhammadiyah Kulonprogo, walaupun di dalam peraturan pondok pesantren itu berada di bawah majelis Dikdasmen Wilayah.

Struktur organisasi sekolah adalah susunan penempatan orang-orang dalam suatu kelompok untuk kerjasama antara orang-orang terhadap kewajibankewajiban, hak-hak dan tanggung jawab masingmasing untuk mencapai tujuan dan sasaran sekolah 
yang sudah disepakati bersama oleh warga sekolah. Karena kinerja lapangan disekolah tidak akan berjalan lancar apabila tugas dan tanggung jawab tidak diberikan kepada orang yang tepat.Adapun struktur organisasi di SMP Muhammadiyah Al-Manar Boarding School sama halnya dengan sekolah reguler pada umumnya, yang terdiri dari kepala sekolah, komite, bendahara sekolah, waka sekolah, bimbingan konseling, tata usaha, dan guru, akan tetapi terdapat sedikit perbedaan yaitu diatas kepala sekolah SMP Muhammadiyah Al-Manar ini ada pesantren. Jika di sekolah lain yang berbasis Muhammadiyah pasti ada majelis, namun di SMP Muhammadiyah Al-Manar Boarding School kepala sekolahnya di bawah tanggung jawab Pesantren, dengan pengembangan utama di pesantren yang semuanya harus di pesantren.

\section{Proses Konflik}

Sebuah konflik tidak akan terjadi secara tibatiba, akan tetapi terjadi melaui urutan-urutan tertentu. Ada 3 tahap proses terjadinya konflik, diantaranya tahap pertama konflik terjadi dalam kehidupan seharihari, tahap kedua adanya tantangan dan tahap ketiga konflik mencapai tahap tantangan. Robbins membagi konflik terjadi lima tahap antara lain:

1. Oposisi atau Ketidakcocokan Potensial

Tahap konflik berawal dari komunikasi antar seseorang, dalam proses ini tidak langsung menuju ke konflik tetapi kondisi yang akan menciptakan konflik itu sendiri.

\section{Kognisi dan Personalia}

Tahap ini mengkondisikan di tahap pertama yang mana mempengaruhi secara negatif. Kondisi ini lebih mendorog ke konflik apabila satu tahap mempengaruhi.

\section{Maksud}

Tahap ini berada pada persepsi dan emosi seseorang dan perilaku seseorang secarang terangterangan. Tahap maksud merupakan keputusan untuk bertindak dengan satu cara tertentu.

\section{Perilaku}

Konflik ini secara nyata untuk melaksanakan maksud setiap pihak, tetapi perilaku-perilaku ini memiliki rangsangan yang terpisah dari maksud tertentu.

\section{Tahap Hasil}

Tahap Hasil dapat fungsional, artinya konflik itu menghasilkan suatu perbaikan kerja kelompok, atau disungsional dalam arti merintangi kerja kelompok.

Di SMP Muhammadiyah Al-Manar Boarding School yang mendorong terjadinya sebuah konflik adalah menyamakan visi dan misi sekolah antara SMP Muahammadiyah Al-Manar Boarding School dengan Pondok Pesantren Al-Manar, hal ini terjadi karena adanya suatu perbedaan persepsi, ada bebarapa guru yang latar belakang pendidikannya bukan santri (tidak pernah mondok), sehingga muncul konflik karena adanya sudut pandang yang berbeda disebabkan mereka tidak terbiasa dengan kebiasaan yang ada di lingkungan pesantren, kemudian ketika sudah di SMP Muhammadiyah Al-Manar Boarding School mereka harus memahami pesantren beserta kehidupannya. Semua guru dan pengurus pondok pesantren harus menyamakan visi misi karena sekolah sudah terikat dengan pesantren. Misalnya, pembelajaran yang ada didalamnya harus mempunyai daya eksistensi pesantren dan sekolah selalu menerapkan bagaimana menjunjung tinggi nilai-nilai keislaman sesuai dengan Al-Qur'an dan As-Sunnah, kemudian yang ketiga sekolah memanagemen pendidikannya dengan memasukan nilai-nilai keagamaan, jadi apapun yang ada didalam sekolah mulai dari managemen pendidikan, managemen sekolah secara luas ataupun managemen pendidik haruslah berwawasan yang selalu condong kepada keislaman, karena sekolah kultur yang diangkat sekolah adalah kultur pesantren dan juga kultur yang diangkat ini menjadikan manusia-manusia yang didalamnya memiliki spirit keilmuan keislaman yang tinggi dan mampu berdaya saing. Karena dalam islam, konflik merupakan sarana untuk menyatukan pemahaman, bukan hanya sebagai tujuan utama saja melainkan saling memberi masukan dan saling bertentangan itu tanda bahwa banyak ide pemikiran yang banyak dan terkesan berilmu. Dengan menjaga keislaman, keilmuan, kemandirian, kesedehanaan dan kebersamaan, tiang pesantren ini harapannya menjadikan sekolah ini mampu melahirkan orang-orang yang memiliki integrasi yang baik guna mewujudkan cita-cita islam yang nantinya berguna bagi nusa dan bangsa.

\section{Penyelesaian Konflik}

Setiap kegiatan organisasi tentu melibatkan banyak orang, selain kerja sama untuk mencapai tujuan organisai, tidak jarang juga terjadi permasalahan yang disebabkan dari perbedaan pandangan, ketidak cocokan pendapat dan lainnya, maka hal yang demikian adalah seuatu kewajaran yang pasti terjadi disetiap badan keorgnisasian. Walaupun konflik sebuah kewajaran, maka dalam penanganannya butuh sebuah alat yang disebut manajemen konflik untuk mengatasi masalah yang terjadi, karena fungsi dari alat tersebut adalah menelaah atau evaluasi dari permasalahan yang terjadi, juga berbedaan sikap emosional dan strukturstruktur yang ada. Selain itu kemampuan dalam managemen konflik menjadikan seorang lebih berpengalaman ketika menghadapi konflik yang terjadi.

SMP Muhammadiyah Al-Manar Boarding School menerapkan kebijakan yaitu menyamakan visi misi yang ada di sekolah dengan pesantren Al-Manar. Di pesantren ini pengembangan keislaman sangat kuat. Misalnya hafalan, akhlak, dan adab 
dipemahaman keislaman ini juga berlaku di sekolah yang mana diharuskan untuk masukkan ke pelajaran keagamaan maupun non keagamaan dan semua guru mata pelajaran harus memasukkan nilai-nilai keislaman di dalam pembelajaran, di tahun ini sekolah penerbitkan buku pembelajaran sains kelas 1 semester 1 karena sekolah ingin anak-anak mengenal sains sebagaimana sains adalah bagian keagamaan agama islam maka didalam buku yang sudah di terbitkan dan disusun oleh guru mata pelajaran IPA itu didalamnya terdapat sudut pandang keislaman, contohnya materi mengenai pengukuran maka didalam buku tersebut ditampilkan ayat-ayat yang berkaiatan dengan pengukuran maka anak-anak akan mengetahui bahwa islam itu adalah kaffah (menyeluruh) yang tidak hanya berbicara kewajiban beribadah. Contoh lainnya yaitu mengenai materi perkembangbiakan, maka peserta didik akan tahu bahwa ternyata di dalam Al-Qur'an

\section{PENUTUP}

SMP Muhammadiyah Sewu Galur mengalami perubahan nama sekolah yang pada akhirnya menjadi SMP Muhammadiyah Al-Manar Boarding School. Selain mengalami perubahan nama sekolah, SMP Muhammadiyah Al-Manar Boarding School juga mengalami pasang surut dalam jumlah anggota peserta didik. Hingga dengan seiringnya waktu, keadaan sekolah mulai membaik serta dengan kebijakan baru yaitu adanya pesantren Al-Manar yang menjadi bagian dari SMP Muhammadiyah Al-Manar Boarding School. Visi dan misi yang diterapkan antara keduanya sama, sehingga menimbulkan konflik. Konflik ini terjadi karena beberapa guru yang latar belakangnya bukan seorang santri (tidak pernah mondok), sehingga menimbulkan sudut pandang yang berbeda.

Kepala sekolah sebagai pemimpin sekolah memanage konflik melalui strategi yaitu dengan sosialisai, dengan sosialisasi ini kepala sekolah memberikan pemahaman kepada guru tentang visi misi yang dipermasalahkan. Bahwa dengan menyamakan visi dan misi ini diharapkan dapat menghubungkan pelajaran umum dengan keislaman serta dapat menciptakan kultur yang baik sesuai dengan syariat islam. Karena konflik ini termasuk konflik intraorganisasi, maka kepala sekolah juga membuka ruang untuk bermusyawarahh dengan para guru untuk memecahkan masalah, baik dalam pembelajaran dengan peserta didik maupun hubungan dengan sesama.

\section{REFERENSI}

terdapat ayat menyebutkan tentang proses terjadinya manusia.

Adapun Kepala Sekolah dalam mengatasi konflik yang terjadi di SMP Muhammadiyah AlManar Boarding School yaitu dengan cara mengadakan sosialisasi dengan para guru tentang visi misi sekolah dan pesantren. Bahwa dengan menyamakan visi dan misi ini diharapkan siswa dapat; berfikir luas, yaitu dapat menghubungkan pelajaran umum dengan keislaman serta dapat menciptakan kultur yang baik sesuai dengan syariat islam. Kepala sekolah sangat memahami kondisi dan latar belakang setiap guru, dengan begitu selain memberi sosialisasi juga mengadakan musyawarah bersama untuk memecahkan masalah, baik dalam pembelajaran dengan peserta didik maupun hubungan dengan sesama.

Hendajany, Nenny. 2015. Efektivitas Tipe-Tipe Sekolah Menengah Pertama Di Indonesia. Jurnal Ekonomi Dan Studi Pembangunan. Vol, 16. No, 01.

Muslim, Ahmad. 2014. Manajemen Konflik Interpersonal Di Sekolah. Jurnal Paedagogy. Vol 1, No 1 .

Mulyasa, E. (2003). Menjadi Kepala Sekolah Profesional: Dalam Konteks Menyukseskan MBS dan KBK, Bandung: PT Remaja Rosdakarya.

Nata, Abuddin. 2003. Manajemen Pendidikan Mengatasi Kelemahan Pendidikan Islam di Indonesia. Jakarta: Predana Media.

Puspita, Weni. 2018. Manajemen konflik (Suatu Pendekatan Psikologi, Komunikasi, dan Pendidiikan). Yogyakarta: CV Budi Utama.

Soetopo, Hendyat. 2010. Perilaku Organisasi, Teori dan Praktek di Bidang Pendidikan. Bandung: Remaja Rosdakarya.

Syah, Muhibbin dan Inten Nurmalasari. 2019. Manajemen Personalia Dalam Pemberdayaan Di SMP Muslimin 5 Kota Bandung. Jurnal Kependidikan. Vol, 07. No, 01.

Syukur, Fatah. 2011. Manajemen Pendidikan Berbasis pada Madrasah. Semarang: PT. Pustaka Rizki Putra.

Zulkarnain, Widan. 2015. Manajemen Konflik Dalam Pelaksanaan Pendidikan di Sekolah. K. (2004). Pengantar Sosiologi. Jakarta: Lembaga Penerbit Fakultas Ekonomi Universitas Indonesia. 